УДК 662.997

\title{
ПАССИВНЫЕ ДОМА В УКРАИНЕ И СТРАНАХ СНГ
}

Божко И.К., Лысенко О.Н., Гончарук С.М., Калинина М.Ф., канд. техн. наук

Институт технической теплофизики НАН Украины, ул. Желябова, 2а, Киев, 03680, Украина

Проведено короткий огляд та наведені умови і перспективи створення пасивних будинків в Україні та країнах СНД.
Проведен краткий обзор и указаны условия и перспективы создания пассивных домов в Украине и странах СНГ.

Библ. 22, рис. 9.

Ключевые слова: энергосбережение, энергоэффективность, пассивный дом.

Одной из основных целей энергетической стратегии Украины на период до 2030 года является снижение удельных затрат в производстве и использование энергетической продукции за счет рационального ее потребления, внедрения энергосберегающих технологий и оборудования, рационализации структуры общественного производства и снижение удельного веса энергоемких технологий. Решение данной задачи возможно путем создания предпосылок для коренного уменьшения энергоемкости отечественной продукции за счет внедрения новых технологий, прогрессивных стандартов, современных систем контроля, управления и учета на всех этапах производства, транспортировки и потребления энергетических продуктов; развитие рыночных механизмов стимулирования энергосбережения во всех отраслях экономики [1].

В частности, решение проблемы энергосбережения в коммунальной энергетике возможно путем строительства энергоэффективных, пассивных сооружений, зданий «ноль энергии» и «ноль энергии +». Большинство зданий, эксплуатируемые в Украине, довольно сложно привести до уровня энергоэффективного сооружения, поэтому весомый акцент необходимо ставить именно на строительство новых зданий с высоким классом энергоэффективности.

В статье рассмотрим некоторые из реализуемых проектов энергоэффективных зданий в Украине и странах СНГ.

Украина. Энергосберегающие здания в Украине сейчас находятся лишь на начальном этапе развития. Только в последние несколько лет по- явился практический интерес к энергосберегающим строительным и инженерным технологиям. Одним из сдерживающих факторов строительства домов нового типа выступают высокие финансовые затраты при строительстве.

Важным фактором при сооружении энергоэффективных зданий является владение достоверной информацией по теплотехническим характеристикам энергосберегающих внешних ограждающих конструкций и систем тепло-, водо-, электроснабжения и вентиляции в реальных условиях их длительной эксплуатации. Именно с этой основной целью в Институте технической теплофизики НАН Украины построено научнотехническую технологическую теплофизическую лабораторию по энергоэффективности зданий, которая представляет собой энергоэффективный дом пассивного типа «ноль энергии» (рис. 1).

Основным преимуществом этого дома среди зданий пассивного типа, построенных в Украине, является создание разветвленной автоматизированной измерительной системы, которая оснащена теплосчетчиками, счетчиками электроэнергии, датчиками температуры, теплового потока, влажности и соответствующими измерительно-контрольными устройствами, компьютерной системой сбора, обработки и визуализации данных. Также внедрены различные современные системы, использующие альтернативные и возобновляемые источники энергии (энергия солнечного прямого и рассеянного излучения, энергия ветра, энергия сжигания твердого биотоплива для резервного или аварийного теплоснабжения, те- 
пловая энергия природного грунта, воздуха, воды в водозаборной скважине, утилизация тепловая энергия уходящих дымовых газов и т.д.). Измерительные датчики размещаются в строительных конструкциях, в системах теплоснабжения и вентиляции, в окружающей почве, воздухе и помещениях (непрерывные измерения полей температур, тепловых потоков, влажности, давления, расхода воздуха, расхода воды, расхода тепловой энергии, внешних климатических параметров).

Особенности конструкции дома: здание строится как сооружение облегченного типа (облегченные плиты перекрытия и стены) без потерь прочностных характеристик, с различными вариантами схем утепления ограждающих конструкций, цоколь углублен в грунт до 2,5 м, на северной стороне без окон и дверей, основной вход через тамбурную пристройку. Данное здание состоит из двух этажей, цокольного этажа, мансарды и неотапливаемого технического помещения для размещения вентиляционной установки рекуперативного типа и экспериментальной тепловой холодильной камеры, которая позволяет определить теплофизические характеристики строительных материалов в реальных условиях их эксплуатации. В сооружении реализована односкатная крыша, ориентированная на юг под углом 33, что в свою очередь позволяет эффективно использовать ее площадь для размещения на ней солнечных коллекторов. С материалов для сооружения несущей конструкции здания используются отечественные строитель- ные материалы: пено- и газобетон, ракушник, арболит, шлакоблоки, дерево, керамические блоки, керамический дырчатый кирпич и т.п. Причем каждая внешняя стена в помещениях дома построена из различного строительного материала. $\mathrm{C}$ целью установления максимально возможной теплоизоляции здания, для утепления применяются различные варианты внешнего утеплителя. Теплоизоляционный слой энергоэффективного пассивного дома составляет так называемую тепловую воздушную завесу, обеспечивающуюся теплотой грунта.

Разработанная поливалентная система теплообеспечения здания пассивного типа на основе теплового насоса и гелиоколлекторов предусматривает систему, которая регулируется в зависимости от температур внешнего и внутреннего воздуха. В связи с этим, разработано три режима работы, в зависимости от необходимости в тепло- или холодоснабжении дома: летний (когда температура наружного воздуха выше $21{ }^{\circ} \mathrm{C}$ ), переходной (температура наружного воздуха колеблется от $8^{\circ} \mathrm{C}$ до $21^{\circ} \mathrm{C}$ ) и зимний режимы (температура наружного воздуха ниже $\left.8{ }^{\circ} \mathrm{C}\right)$. Электроснабжение дома представляет собой систему, которая содержит лопастной ветроагрегат пропеллерного типа, систему электроаккумулирования высокой емкости, солнечные фотовольтаические панели, а также комбинированные солнечные панели, когенерационную установку, термоэлектрические модули.

Вентиляция - трехвалентная система: 1) при-
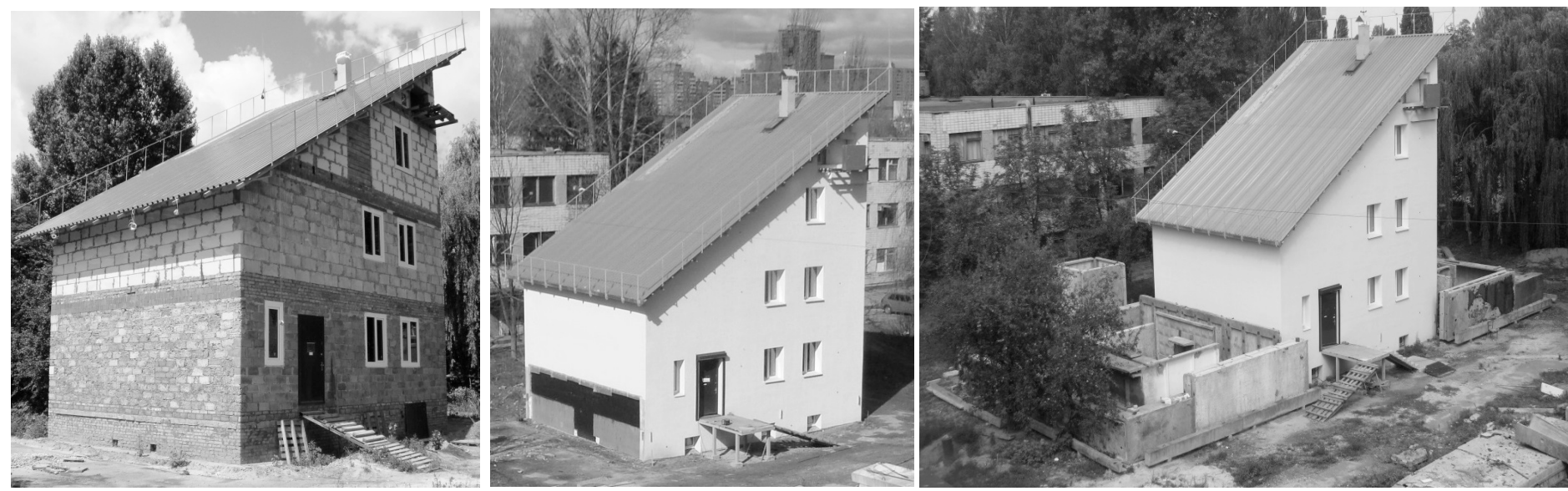

Рис. 1. Энергоеффективный дом пассивного типа «ноль энергии» (Институт технической теплофизики НАН Украины, г. Киев, Украина). 
точно-гравитационная пассивная система; 2) принудительная вентиляция через грунтовые теплообменники; 3) приточно-вытяжная рекуперативная система (с возможностью дополнительного нагрева воздуха теплоносителем из системы отопления) [2-4].

Еще один пример реализованного в Украине проекта пассивного здания это экодом под названием дом «Солнца», который построен в г. Киеве в 2008 году (рис. 2, а). С 2010 года зданий архитектора «Дома Солнца» в разных городах и селах Украины стало уже несколько. Среди них: пассивный дом «Солитер» в с. Зозули Васильковского р-на Киевской обл. (рис. 2, б), в с. Боромики Черниговской обл. (рис. 2, в), пассивный детский дом семейного типа «ХолмЭкодом» в с. Михайловка Каневского р-на Черкасской обл. (рис. 2, г), экодома в г. Симферополь (рис. 2, д) и с. Ясногородка Макаровского р-на Киевской обл. (рис. 2, е) и т. д.

Все эти дома созданы одним автором по одним и тем же основным принципам строительства пассивных домов, а именно: использование для строительства природных и экологически чистых материалов, не выделяющих вредных эмиссий при их эксплуатации; применение в конструкциях здания достаточного количества аккумулирующего (зимой - холод, летом - тепло) массива стен и перекрытий. Ориентация оконных конструкций на юг позволяет получать максимальное количество солнечной энергии в зимнее время.

Также к пассивным системам тепловой защиты здания можно отнести: глухую изоляцию северного фасада (отсутствие окон и дверей); расположение на севере вспомогательных зон, которые были бы "тепловым буфером" между холодным и теплым жилым пространством; устройство качественной теплоизоляции и обеспечение герметичности здания; отсутствие тепловых мостов в тепловой оболочке здания; использование во внутренней отделке помещений природных диффузионно-открытых материалов (глина, бумажные обои, дерево, натуральный линолеум и др.). Уравновешивание относительной влажности воздуха в помещениях и постоянное поддержание ее на уровне $50 \%$, отказ от конвекционных систем отопления и охлаждения зданий, которое, по мнению некоторых специалистов, приводит к перегреву и пересыханию воздуха зимой и значительного переохлаждения его летом.

Использование низкотемпературных систем отопления и охлаждения здания с помощью излучающих настенных теплообменников и применение системы контролируемой приточно-вытяжной вентиляции с рекуперацией теплоты создают комфортные условия для пребывания человека внутри здания в течении всего года. Уменьшение количества энергии для производства строительных материалов и конструкций, а также использования местных материалов снижают затраты энергии на транспортировку элементов. Использование строительных материалов, производство, эксплуатация и утилизация которых не влияет на окружающую среду, а также, утилизация и вторичное использование отходов производства значительно снижает воздействие на окружающую среду.

Использование меньшего количества энергии для отопления, охлаждения и вентиляции здания; использование инженерных систем с высоким КПД на основе возобновляемых источников энергии; правильно составленного и рассчитанного теплового баланса здания (в том числе и учёт теплопоступлений от людей и бытовых приборов) составляют основную статью повышения энергоэффективности здания [5-7].

Одним из примеров частных энергоэффективных домов пассивного типа - здание, построенное под Киевом (рис. 3). При строительстве для столбов фундамента выбрана металлическая труба диаметром 100 мм, высота столба 1000 мм. Так как уровень поверхности участка неровный, то высота столбов, выступающих над землей, колебалась от 300 до 500 мм. Столбы соединялись уголками, на которые ложилось листовое оцинкованное железо. Листы укладывались внахлест, соединялись заклепками и герметизировались бутиловой лентой. Поверх оцинкованного железа укладывалась полиэтиленовая пленка для обеспечения гидроизоляции пола. Заполнение пространства стен, пола, перекрытий и потолков проводилось жидким пеноизолом, который заполняет все полости и создает сплошной (без разрывов) слой теплоизоляции. Появление «мостиков холода» при использовании такой технологии - невозможно.

Для строительства каркаса стен выбран де- 


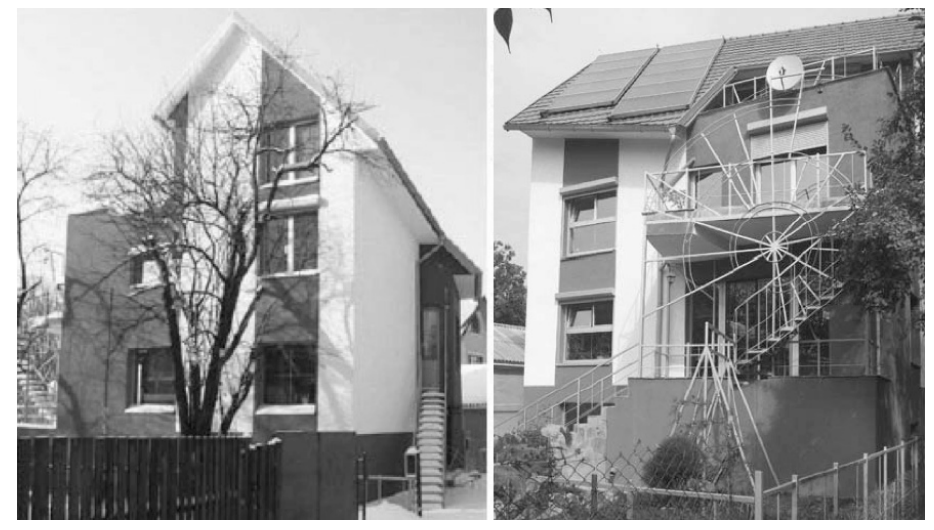

a)

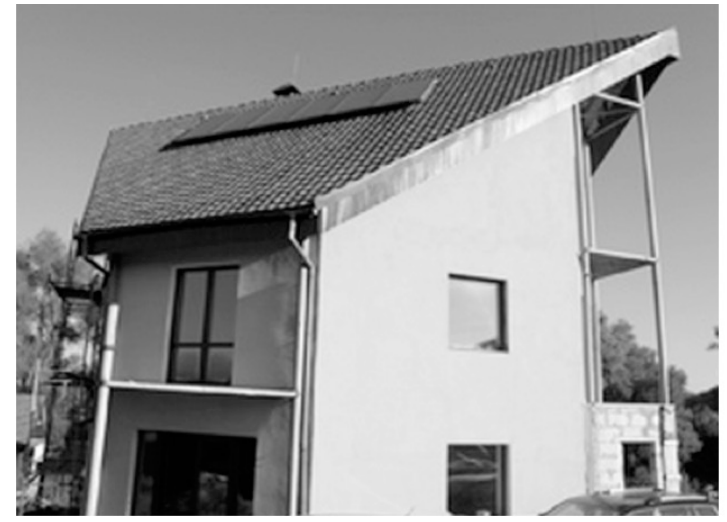

B)

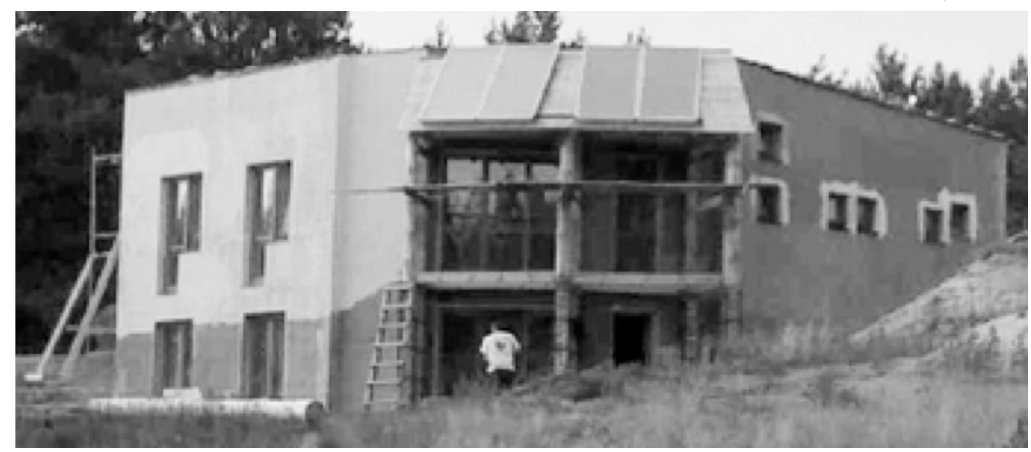

2)
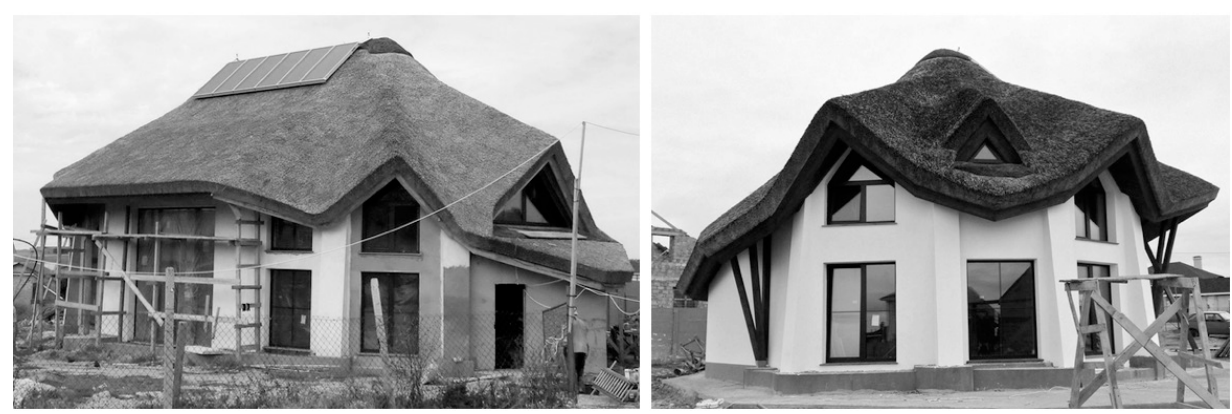

d)

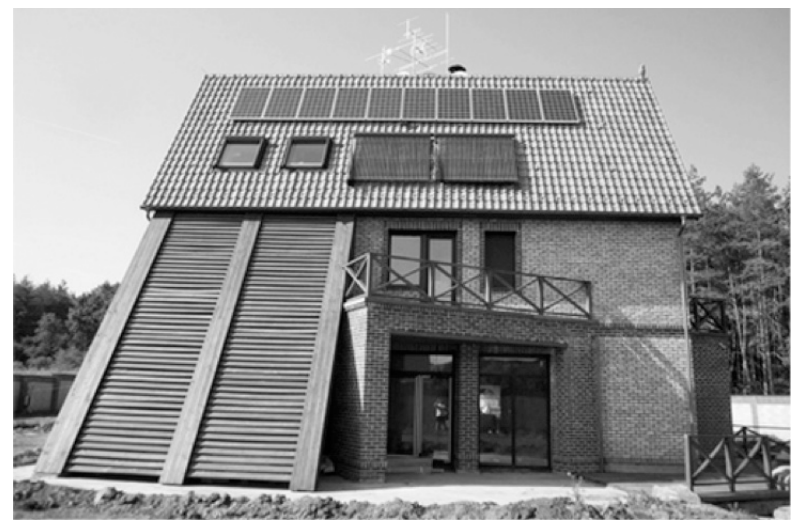

б)

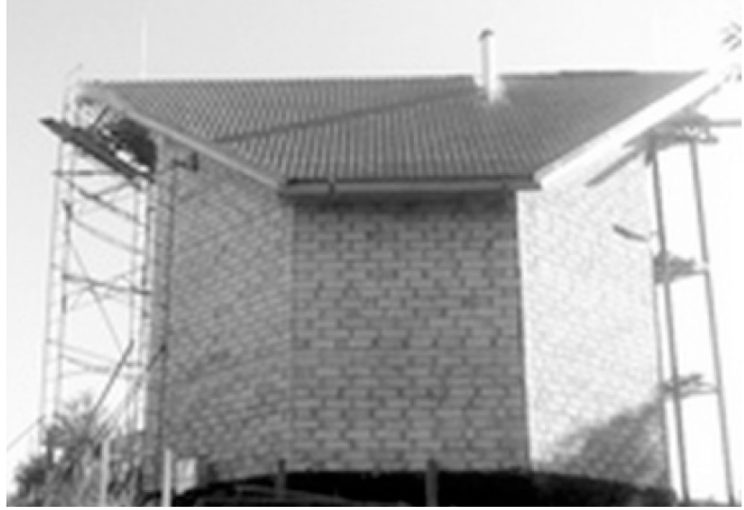

西
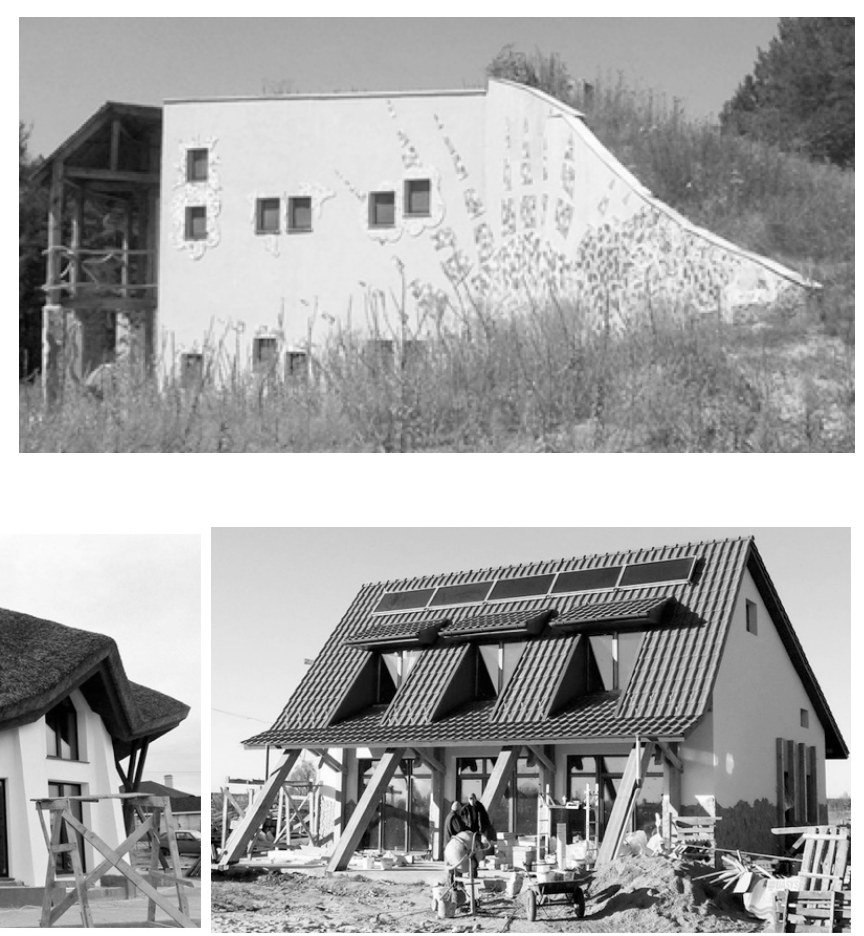

e)

Рис. 2. Примеры пассивных домов в Украине (2. Киев (а), с. Зозули Васильковского р-на Киевской обл (б), с. Боромики Черниговская обл. (в), с. Михайловка Каневского р-на Черкасская обл. (2), 2. Симферополь (д), с. Ясногородка Макаровского р-на Киевской обл. (е)) [5]. 

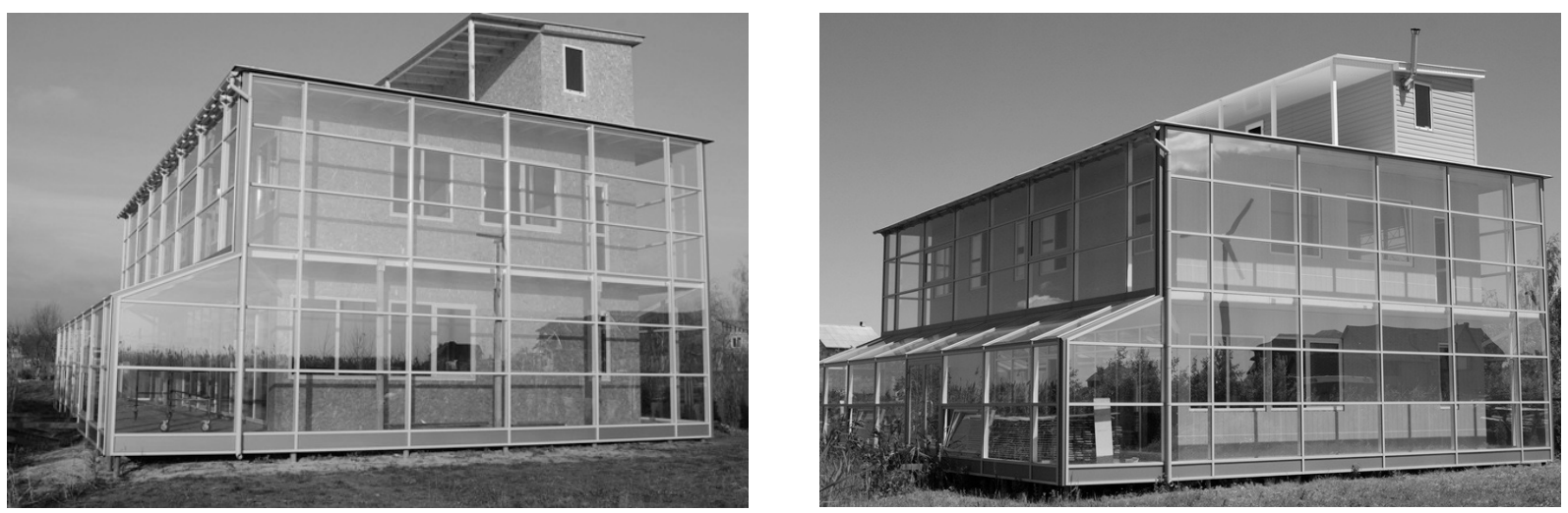

Рис. 3. Частный энергоэффективный дом пассивного типа в Киевской обл. (Украина) [8].

ревянный брус сечением $(50 \times 150)$ мм. Каркас обшит плитами ОСП, прочность которых в полтора раза выше, чем прочность дерева такой же толщины. Толщина стены между плитами ОСП 150 мм. Это пространство заполнялось пеноизолом. Пеноизол не горит (пожароустойчив), его не едят грызуны и при попадании в почву служит удобрением.

Крыша плоская и закрыта ПВХ мембраной белого цвета. Периметр эксплуатируемой крыши закрывается застекленным парапетом. Каркас стеклянной галереи дома изготавливается из фасадного алюминиевого профиля. Остекление - самоочищающееся стекло толщиной 6 мм. Дом, площадью 395 м² был построен за три месяца. Эквивалентное сопротивление теплопере-

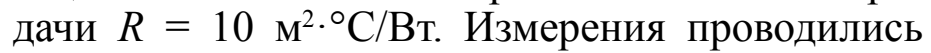
при температуре наружного воздуха - минус (20 ... 25) ${ }^{\circ} \mathrm{C}$. Для поддержания постоянной температуры внутри дома достаточно источника теплоты мощностью до 2 кВт. При этом потери теплоты на первых двух этажах, площадью 233 м² составили 900 Вт/ч, потери теплоты на третьем этаже, площадью 39,6 м² $^{2} 600$ Вт/час.

Большое различие в потере теплоты на квадратный метр площади пола объясняется тем, что первые два этажа закрыты галереей от холодного ветра. Третий этаж не защищен галереей, а вытянутая форма с большой площадью стен способствует дополнительному увеличению потерь теплоты. Общий объем здания составил 1076 м $^{3}$ : объем застекленной галереи - 379 м³ «теплая» часть дома - $697 \mathrm{~m}^{3}$.

Вентиляция здания: наружный воздух поступает в застекленную галерею через теплообменное устройство, расположенное под водой (или землей). Температура воды на дне озера не опускается ниже $4{ }^{\circ} \mathrm{C}$ зимой и $10{ }^{\circ} \mathrm{C}$ - летом. Таким образом, холодный зимний воздух нагревается до $+4{ }^{\circ} \mathrm{C}$, а теплый летний воздух - охлаждается до $+10{ }^{\circ} \mathrm{C}$. Далее воздух из галереи, через приточно-вытяжные системы с рекуперацией тепла, поступает в «теплую» часть дома. После рекуператора приточный воздух поступает в систему очистки где он увлажняется или осушается.

Для обогрева трех этажей пассивного дома применена многоярусная система отопления. Для этого на втором и третьем этажах установлены, изготовленные из нержавеющей стали, теплонакопительные колпаки. Колпак представляет собой перевернутый вверх дном сосуд, в котором вход горячих дымовых газов из печи, и выход охлажденных, расположены в противоположных сторонах нижней части. Разогретый до $300 \ldots$ $400{ }^{\circ} \mathrm{C}$ газ из печи поступает в колпак на втором этаже. Охлаждаясь в колпаке газ, опускается вниз к выходу и по трубе поступает в такой же колпак на третьем этаже. Отдав теплоту на третьем этаже, максимально охлажденный газ выходит через трубу на улицу. Поскольку отбор теплоты дымовых газов происходит на достаточно большом расстоянии от топки, то это значительно повышает эффективность сгорания топлива. Такой многоярусный отбор теплоты более чем вдвое увеличивает эффективность использования топлива. Печь на дровах можно легко заменить тепловым насосом или электрическим обогревателем [8].

Молдова. Первый пассивный дом в Молдове был построен в районе Кодру, в 5 км от города Кишинева в 2013 году. Рабочее название проекта Passivhaus Codru Quince (PCQ) (рис. 4). PCQ - 
это 3-х этажный частный жилой дом площадью 301,3 $\mathrm{m}^{2}$ [9].

Солнечная инсоляция поступает в пассивный дом через двухкамерные металлопластиковые окна с энергосберегающим низкоэмиссионным покрытием. Пассивный дом PCQ размещен на склоне холма, угол наклона которого около $10^{\circ}$ и направлен на юго-запад. PCQ ориентирован по сторонам света с углом поворота на $23^{\circ}$ в юго-восточном направлении, в связи с особенностями ландшафта местности. Это способствует получению максимальных поступлений теплоты от солнечной радиации в течение зимнего периода. Именно на этом фасаде сосредоточены основные светопрозрачные конструкции, в то время, как на северо-западном фасаде расположены только два небольших окна.

В проекте пассивного дома PCQ реализуются конструкции каменно-железобетонного здания: железобетонный каркас с заполнением внешних стен местным материалом - каменными блоками «Котилец» толщиной 390 мм - с армированием кладки металлической сеткой. Фундамент дома - железобетонные блоки по монолитной плите с поясом по верху фундамента. Учитывая крутизну склона строительной площадки и неблагоприятное состояние почв (под основанием фундамента наличие трещин, возможность обводнения т.д.), проектированию фундамента было предоставлено особое внимание. Проектом также предусмотрено подпорную стенку, предотвращающую возможность оползней по склону.

Для обеспечения низких тепловых потерь здания все внешние поверхности ограждающих конструкций - стен, крыш, плит по грунту - покрыты сплошным слоем тепловой изоляции толщиной 200 мм. При РНРР расчетах вычислено использования несколько вариантов тепловой изоляции ограждающих конструкций: натуральный целлюлозный утеплитель - эковата «Юнизол» $\left(\lambda=0,04 \mathrm{BT} /\left(\mathrm{M}^{\circ}{ }^{\circ} \mathrm{C}\right)\right)[10]$, плитный утеплитель «RockWool» $\left(\lambda=0,038-0,041 \mathrm{BT} /\left(\mathrm{M}^{\left.\cdot{ }^{\circ} \mathrm{C}\right)}\right)\right.$ [11], плитный утеплитель «Celotex FR5000» $\left(\lambda=0,021 \mathrm{BT} /\left(\mathrm{M}^{\circ} \mathrm{C}\right)\right)[12]$ и утеплитель из пенополиуретана $\left(\lambda=0,02 \mathrm{BT} /\left({ }^{\cdot{ }^{\circ}} \mathrm{C}\right)\right)$.

Системой теплоснабжения пассивного дома предусмотрено использование системы вентиляции с рекуперацией теплоты. В качестве источника тепловой энергии для систем отопления и горячего водоснабжения используются солнечные тепловые коллекторы.

Одним из путей снижения использования электрической энергии, которые были воплощены в проекте, является использование энергоэффективного светодиодного освещения в помещениях. Планируется достичь дополнительного сбережения энергии за счет внедрения технологий «Умный Дом».

Согласно с проведенными расчетами энергетических балансов пассивного дома PCQ удельное потребление энергии для отопления составляет 12 кВт.час/(м².год); удельное потребление первичной энергии (ГВС, отопление, охлаждение, электроэнергия и бытовые приборы) составляет $65 \mathrm{\kappa Bт} \cdot ч а с /\left(\mathrm{M}^{2} \cdot\right.$ год).

Плановое подорожание строительства: + $10 \%$
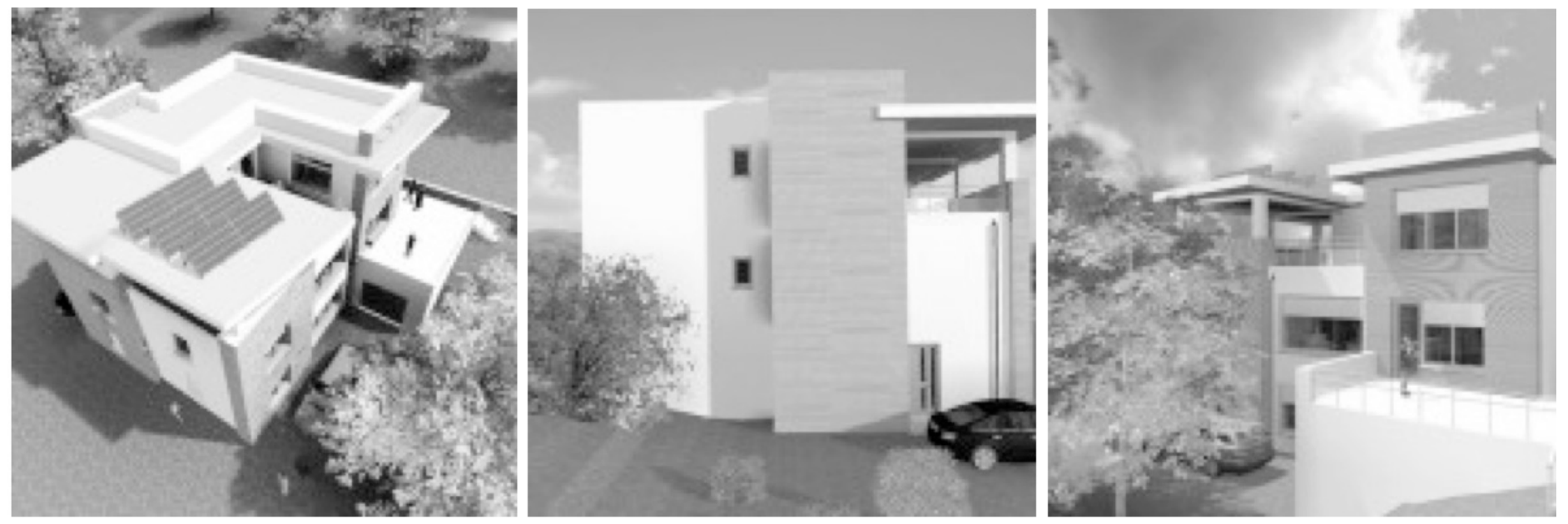

Рис. 4. Эскиз проекта пассивного дома РСQ (Молдова) [10]. 
в сравнении с обычными домами Молдовы. Плановые сбережения средств за использование энергии на отопление составляют 930... 1030 долларов в год (за отопительный период).

Белоруссия. Впервые о намерениях создания пассивного дома в Беларуси стало известно еще в 2011 году [13]. В 2012 г. в Дзержинске начались строительные работы по созданию первого частного пассивного жилого дома [14]. Преимуществами такого жилища является минимальное потребление энергии и отсутствие влияния на окружающую среду.

В основу концепции легли немецкие стандарты «пассивного» дома, созданные еще в 90-е годы.

Ожидается, что дом будет использовать примерно в 4 раза меньше энергии, чем стандартные частные здания. А именно - около 2,5 кубометров природного газа на квадратный метр в год. Также особого внимания заслуживает приточно-вытяжная система вентиляции, обеспечивающей целый год поступление свежего воздуха.

Армения. Официальное открытие жилого дома (рис. 5), построенного в рамках программы "Социальное жилье в благоприятных условиях Горис-2", произошло 18 декабря 2012 в г. Горис Сюникской области Армении [15].

Мероприятия по повышению энергетичес- кой эффективности здания включили теплоизоляцию внешних стен, колонн, балок и перекрытий здания, установку энергоэффективных окон и дверей. Для обеспечения контроля использования горячей воды и энергии во всех квартирах были установлены аллокаторы теплоты и счетчики горячей воды. В квартирах, а также в общих помещениях дома, были установлены энергоэффективные системы освещения. Впервые в строительной практике Армении на окнах здания были установлены приточные клапаны, с целью обеспечения достаточной вентиляции квартир и избегания температурных колебаний.

В результате внедрения энергоэффективных мероприятий существенно повысилось качество жилищных условий в квартирах, а затраты на энергию для жителей снизились более, чем на 50 \%.

Россия. Общая площадь всех зданий, эксплуатируемых в России составляет около 5 млрд. м $^{2}$. Для их отопления необходимо 400 млн. тонн условного топлива в год или более трети энергоресурсов страны. Особенно остро эта проблема стоит в коммунальном хозяйстве, которое потребляет до 20 \% электрической и $45 \%$ тепловой энергии, производимой в стране. На единицу жилой площади в России расходуется в $2 . .3$ раза больше энергии, чем в Европе. И это не является следствием холодного климата. Несмотря на

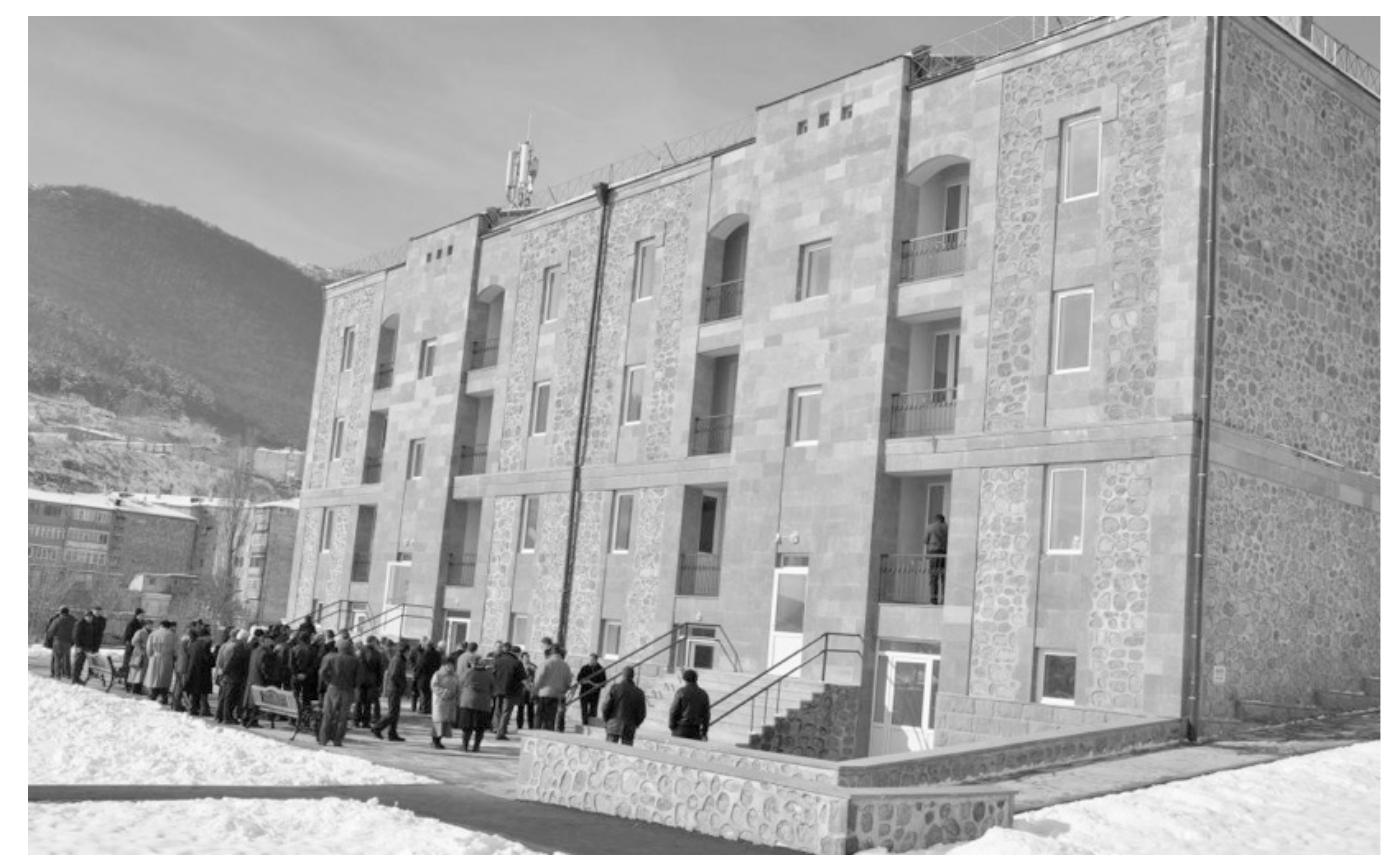

Рис. 5. Энергоеффективный жсилой дом в г. Горис (Армения) [16]. 
суровые условия, вопросам энергосбережения не оказывалось серьезное значение - благодаря крайне низкой стоимости энергии.

Инновационный центр "Сколково" (рис. 6). Согласно информации фонда "Сколково", первым зданием, построенным на территории этого инновационного центра, будет "Зеленый дом", разработан с использованием современных энергосберегающих технологий [16].

Инноград «Сколково" - это особая территория в Московской области, где будут созданы специальные условия для разработок и исследований в области энергосбережения и энергоэффективности, телекоммуникационных, ядерных, компьютерных и биомедицинских технологий. Кроме этих направлений работы, в иннограде будет еще одно приоритетное направление - эффективное градостроительство. В рамках этого направления на основе энергоэффективных технологий планируется возвести так называемый "Зеленый дом" по аналогии с датским проектом "Зеленый маяк" (рис. 7) [17].

«Зеленый маяк» (Green Lighthouse) - трехэтажное административное здание, принадлежащее к датскому государственному университету. Здание имеет цилиндрическую форму с точки зрения уменьшения потерь, поскольку именно цилиндр имеет минимальную площадь поверх- ности, что приводит к снижению тепловых потерь фасада здания.

Для минимизации выработки углекислого газа в проекте Green Lighthouse внедрен комплекс энергосберегающих технологий и приняты меры для формирования здорового микроклимата в помещениях. Ориентация здания в пространстве осуществлена таким образом, чтобы максимально использовать солнечную энергию, в то время как окна и двери снабжены автоматическими защитными экранами, препятствующие нагреву помещения прямыми солнечными лучами. Мягкий свет, пронизывающий все помещения, и естественная вентиляция достигаются благодаря световым потолочным люкам и огромным атриумом в центре дома. В техническом оснащении здания рационально использованы самые передовые технологии энергосбережения: солнечное теплоснабжение, фотогальванические панели, использование LED - светодиодов для освещения помещений, геотермальное отопление и т.д.

Москва. Проект "Энергоэффективный жилой дом в микрорайоне Никулино-2" (экспериментальный 16-этажный дом) был реализован в 1998-2002 годах в рамках "Долгосрочной программы энергосбережения в Москве". Для мероприятий по энергосбережению, были исполь-
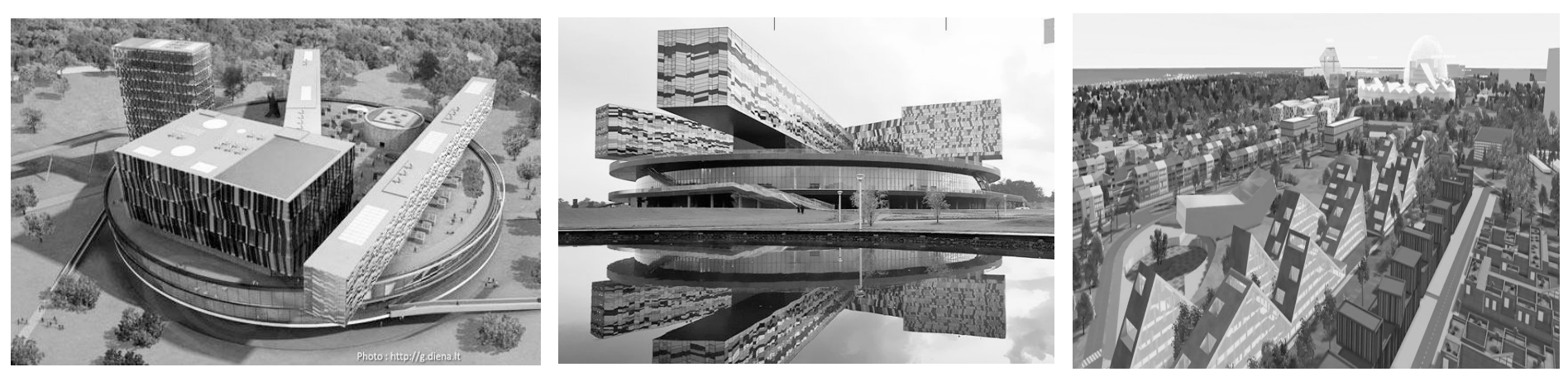

Рис. 6. Энергоэффективный инновационный центр в Сколково (Россия) [17].
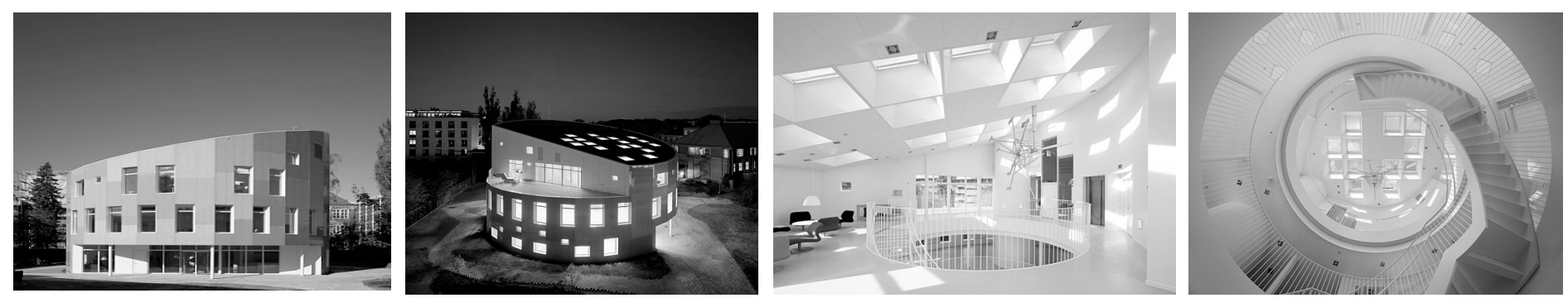

Рис. 7. Экологически чистое здание "Зеленый маяк" (Дания) [18]. 
зованы как современные энергосберегающие технологии (тепловые насосы, автоматизация жизнеобеспечения, ИТП), так и внешние ограждающие конструкции с повышенной теплозащитой. Целью проекта было создание, натурная апробация и последующее внедрение в жилищное строительство города новейших технологий и оборудования, обеспечивающих, как минимум, двукратное снижение энергетических затрат на эксплуатацию жилого фонда.

Стратегия проекта предусматривала реализацию трех основных этапов: 1) проведение измерительной компании по натурной оценке теплового режима типового жилого дома (базовый дом); 2) проведение комплексных научных исследований и разработка проекта энергоэффективного жилого дома; 3) строительство энергоэффективного жилого дома и проведение измерительной компании по натурной оценке его теплового режима [18].

В результате проведения комплексных научных исследований был применен ряд конструктивных решений для повышения энергоэффективности здания: меры по повышению уровня теплозащиты внешних ограждающих конструкций, которые, за счет применения современных энергоэффективных материалов и качественного проекта, позволили снизить общие затраты энергии здания на $34 \%$.

Мероприятия по совершенствованию системы энергообеспечения здания: энергообеспечение здания осуществляется как от внешних источников тепловой и электрической энергии, так и от внутренних - тепловых насосов, использующих теплоту грунта и теплоту удаленного вентиляционного воздуха.

В рамках этого проекта была создана теплонасосная система горячего водоснабжения многоэтажного дома. Поскольку режим работы тепловых насосов, использующих теплоту земли и теплоту удаляемого воздуха, постоянный, а потребление горячей воды переменное, система горячего водоснабжения оборудована бакамиаккумуляторами. Система горячего водоснабжения предусматривает два температурных уровня аккумуляции горячей воды. Первый - низкотемпературный, обеспечивается тепловыми насосами; второй - высокотемпературный - ТЭНами, которые включаются в ночное время суток.

Отопительные приборы - конвекторы, расположенные в подоконном пространстве. Регулирования их теплоотдачи производится терморегуляторами, установленными на конвекторах. В здании установлена поквартирная двухтрубная горизонтальная система водяного отопления с теплосчетчиком на кухне и с термостатическими вентилями на каждом отопительном приборе. Эта система обеспечивает возможность поквартирного учета тепловой энергии и индивидуального регулирования температуры воздуха в помещениях без изменения теплового режима соседних помещений.

Якутия. Первый энергоэффективный 33-х квартирный дом (рис. 8) в поселке Жатай Республики Саха (Якутия) введен в эксплуатацию в 2011 году [19].

В доме предусмотрена усиленная тепловая изоляция стен, цокольного и чердачного перекрытий, за счет чего теплопотери снижены на $10 \%$, двухкамерные окна с аргоновым заполнением позволяют снизить теплопотери на 30\%. Также создается эффект «дома-термоса» за счет заключения мокрой штукатурки по пластиковой сетке, что практически исключает поступление холодного воздуха извне.

В «умном доме» предусмотрено автоматическое поддержание температуры теплоносителя в зависимости от внешней температуры, дистанционное управление параметрами теплоносителя с помощью электронного узла управления, приборы учета расхода количества теплоты и воды в системе отопления, холодного и горячего водоснабжения. Кроме того, освещение помещений предусмотрено с автоматическим управлением - установлены датчики движения и

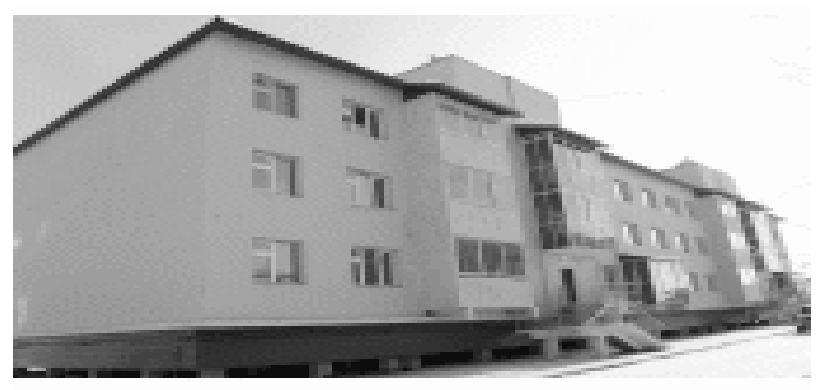

Рис. 8. Энергоеффективный дом (Якутия, Россия) [20]. 
освещенности. Светильники в помещениях оснащены светодиодными лампами, что позволяет экономить до 90 \% электроэнергии. В квартирах предусмотрена рекуперация теплоты выходящего воздуха, которая дает экономию энергии на подогрев воздуха до $50 \%$ и регулирования приборов отопления термостатами. Благодаря применению энергоэффективных технологий жители «умного дома» смогут значительно экономить на платежах за жилищно-коммунальные услуги - по расчетам до $40 . .45 \%$.

Барнаул. В столице Алтайского края, городе Барнауле, сдан первый энергоэффективный дом (рис. 9). В доме установлены солнечные коллекторы для освещения мест общего пользования. Также солнечные коллекторы используются и для горячего водоснабжения. Внедрена система рекуперации, что позволяет нагревать входящий воздух, используя тот, что удаляется. Для обеспечения жителей отоплением и горячей водой создано специальное тепловое поле. Оконное стекло изготовлено с применением нанотехнологий. На него нанесен специальный состав, который обеспечивает сохранение теплоты. Дом имеет высокий класс энергоэффективности "А". Общая экономия энергии составляет 52 \% [20].

Новосибирск. С 1987 года в Новосибирском Академгородке на базе институтов СО РАН создано общественное объединение «Сибирский эксперимент» для строительства индивидуальных домов сотрудникам институтов. Одновременно организован инженерно-технический «Центр экологического домостроения». В 1992 году был разработан первый про-

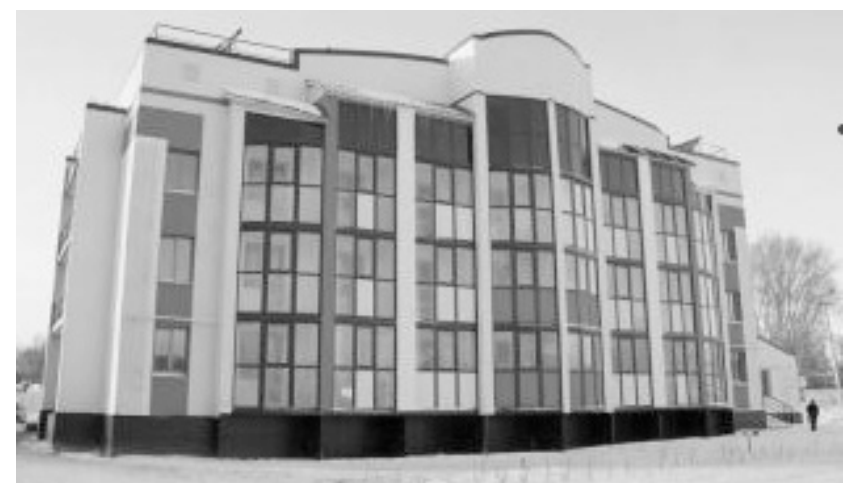

Рис. 9. Энергоэффективный дом (Барнаул, Россия) [21]. ект «экопоселок» для комплексной малоэтажной застройки территории [21-22].

\section{Выводы}

В Украине и странах СНГ существует достаточно большое количество организаций, предприятий частного типа, которые занимаются внедрением энергосберегающих технологий, решающие задачи по снижению энергопотребления и использования альтернативных и возобновляемых источников тепловой энергии, активно пропагандирующих пассивное строительство, приводящие концептуальные условия его создания, но никто не предоставляет мониторинг энергопотребления и конкретные полученные результаты. Поэтому именно этот не решенный вопрос имеет весомое значение на сегодняшний день.

При создании концептуальных условий сооружения зданий пассивного типа одной из существенных условий получения точных и качественных результатов их эксплуатационных характеристик является учет местных климатических данных, которые могут служить определяющим фактором для достижения критериев пассивного дома.

\section{ЛИТЕРАТУРА}

1. Енергетична стратегія Украӥни на період до 2030 року. Схвалено розпорядженням Кабінету Міністрів України від 24 липня 2013 р. № 1071, Київ, 2013. - 166 с.

2. Экспериментальный дом типа «ноль энергии» [Электронный ресурс] / Институт технической теплофизики НАН Украины, отдел теплофизических основ энергосберегающих теплотехнологий. - Режим доступа URL: www://ittf.kiev.ua/ru/экспериментальный-домтипа-ноль-эне/\#more-3125 (дата обращения: 12.05.2014).

3. Долінський А.А. Концептуальні основи створення експериментального будинку типу «нуль енергії» [Текст] / А.А. Долінський, Б.I. Басок, О.М. Недбайло, Т.Г. Беляєва, М.А. Хибина, М.В. Ткаченко, М.П. Новіцька // Будівельні конструкції: Міжвідомчий науково-технічний збірник. - 2013. - Вип. 77. - С. 222 - 227. 
4. Гончарук С.M. Створення експериментального энергоефективного будинку пасивного типу «нуль енергії» [Текст] / С.М. Гончарук, М.Ф. Калініна, І.К. Божко та ін.// Пром. теплотехніка - 2014. - Т. 36, №3. - С. 88-95.

5. Сайm архитектурного бюро “Архитектура и Экология” [Электронный ресурс]. - Режим доступа URL: http://www.ernst.kiev.ua (дата обращения: 12.05.2014).

6. Ернст T. Екосвідомість нації як перед основа переходу до зеленого будівництва [Текст] / Т. Ернст // Екоінформ. - 2011. - № 6. -С. 8-10.

7. Екологічна концеепџія будівлі: “пасивний екодім” [Текст] / Т. Ернст // Екоінформ. - 2011. - №9. - C. 47.

8. Сайm предприятия ТЕХНОЛУЧ [Электронный ресурс] / Энергопассивный дом. - Режим доступа URL: http://tehnoluch.com/ (дата обращения: 12.05.2014).

9. Пасивний будинок. Енергоефективність, екологічність, якість комфорт [Электронный pecypc] / Пасивний Будинок Passivhaus Codru Quince. - Режим доступа URL: http://passive house-igua.com/2012/08/07/passivhaus-codruquince-moldov/ (дата обращения: 12.05. 2014).

10. Целлюлозный утеплитель Юнизол [Электронный ресурс]. - Режим доступа URL: http:// unisol.com.ua/index.php (дата обращения: 12.05. 2014).

11. RockWool: негорючая изоляциия [Электронный ресурс]. - Режим доступа URL: http:// www.rockwool.ua/ (дата обращения: 12.05.2014).

12. Celotex [Электронный pecypc]. - Режим доступа URL: http://www.celotex.co.uk/products/ fr5000 (дата обращения: 12.05.2014).

13. Дмитро Жуков - «Белорусский пассивный дом: To Be, Or Not To Be...» [Текст] // Архитектура и строительство №1 (219) 2011г.

14. Первый пример пассивного дома в Беларуси [Электронный ресурс]. - Режим доступа URL: http://realt.by/news/article/10548/ (дата обращения: 12.05.2014).
15. Энергоеффективное здание в г. Горисе открыло двери для 20 семей [Электронный pecypc]. - Режим доступа URL: http://am.beeca. net/poslednie-novosti/250 (дата обращения: 12. 05.2014).

16. Энергоеффективные дома. История и перспективы развития. [Электронный ресурс]. - Режим доступа URL: http://www.ecology.md/ section.php?section $=$ ecoset\&id=4928\#.U2jKyoF vSn (дата обращения: 12.05.2014).

17. Зеленый маяк - здание задающее новый тренд в эко архитектуре. [Электронный ресурс]. - Режим доступа URL: http:/www.lightonline. $\mathrm{ru} / \mathrm{svet} /$ Architecture/Green_LightHouse.html (дата обращения: 12.05.2014).

18. Энергоеффективный дом: [Электронный ресурс]. - Режим доступа URL: http://www. geaudit.ru/stati/energoeffektivniy-dom (дата обращения: 12.05.2014).

19. Энергоеффективный дом в условиях вечной мерзлоты стал реальностью в Якутии: [Электронный ресурс]. - Режим доступа URL: http://energodoma.ru/novosti/novosti/932-energo effektivnyj-dom-v-usloviyakh-vechnoj-merzlotystal-realnostyu-v-yakutii (дата обращения: 12.05. 2014).

20. Первый энергоэффективный дом открыт в Алтайском крае. [Электронный ресурс]. - Peжим доступа URL: http://www.nanonewsnet.ru/ blog/nikst/pervyi-energoeffektivnyi-dom-otkrytv-altaiskom-krae (дата обращения: 12.05.2014).

21. Сайт института теплофизики им. С.С. Кутателадзе / Экодом. [Электронный ресурс]. - Режим доступа URL: http://www.itp.nsc.ru/ ecodom/ (дата обращения: 12.05.2014).

22. Чунтонов В.С. Опыт проектирования экодома и экопоселения [Текст] / В.С. Чунтонов // Научно-практическая конференция «Энергои ресурсоэффективность малоэтажных жилых зданий» Институт теплофизики им. С.С. Кутателадзе СО РАН, Новосибирск, 19-20 марта. 2013. - C. $23-31$. 


\section{PASSIVE HOUSES IN UKRAINE AND COUNTRIES OF UIC}

\section{Bozhko I.K., Lysenko O.N., Goncharuk S.M., Kalinina M.F.}

Institute of Engineering Thermophysics

of the National Academy of Sciences of Ukraine, vul. Zhelyabova, 2a, Kyiv, 03680, Ukraine

The aim is an overview of passive houses built in Ukraine and countries of UIC. It is shown that this type of energy-efficient construction is possible in countries with different climate (from temperate continental to continental). The task of the work - a comparison of the passive house, which was built at the Institute of Engineering Thermophysics of the National Academy of Sciences of Ukraine with similar houses located in the countries of UIC. Achieved analytical comparison, a comparative analysis of designs and systems of heating of passive homes. Given a description of the design and engineering systems of passive houses in Ukraine and countries of UIC. Shows the status and prospects of development of energy-efficient construction. References 22, figures 9 .

Key worlds: energy conservation, energy efficiency, passive house.

1. Energy Strategy of Ukraine until 2030. Approved by Cabinet of Ministers of Ukraine of 24 July 2013 p. № 1071, Kyiv, 2013. - 166 p. (Ukr.)

2. The pilot house of the "zero energy" [Electronic resource] / Institute of Engineering Thermophysics of NAS of Ukraine, Department of thermophysical bases of energy-saving heat technologies. - Access URL: www: //ittf.kiev.ua/ ru/eksperimentalnyy-dom-tipa-nol-ene/\#more3125 (date accessed: 05/12/2014). (Rus.)

3. Dolinskiy A.A. The conceptual basis for the creation of experimental building of the "zero energy" [Text] / A.A. Dolinskiy, B.I. Basok, O.M. Nedbaylo, T.G. Belyaeva, M.A. Hybyna, M.V. Tkachenko, M.P. Novitska // Budivelni konstruktsiï:
Mizhvidomchy naukovo-tehnichny zbirnik. 2013. - Vol. 77 - P. 222 - 227. (Ukr.)

4. Goncharuk S.M. Create energy efficiency experimental passive house of the "zero energy" [Text] / S.M. Goncharuk, M.F. Kalinina, I.K. Bozhko etc. // Prom. teplotekhnika. - 2014. Vol. 36, №3. - P. 88-95. (Ukr.)

5. Site of architectural office "Architecture and Environment" [Electronic resource]. - Access URL: http://www.ernst.kiev.ua (date accessed: 12/05/2014). (Rus.)

6. Ernst T. Environmental consciousness of the nation as a base to go to the green building [Text] / T. Ernst // Ekoinform. - 2011. - № 6. P. 8-10. (Ukr.)

7. Environmental concept building "passive environmental house" [Text] / T. Ernst // Ekoinform. - 2011. - №9. - P. 47. (Ukr.)

8. Business Website TEHNOLUCH [electronic resource] / Energy-passive house. - Access URL: http://tehnoluch.com/ (date accessed: 05/12/ 2014). (Rus.)

9. Passive House. Energy efficiency, environmental friendliness, quality, comfort [Electronic resource] / Passive House Passivhaus Codru Quince. - Access URL: http://passivehouseigua.com/2012/08/07/passivhaus-codru-quincemoldov/ (circulation date: 12.05.2014). (Ukr.)

10. Cellulose insulation Yunizol [Electronic resource]. - Access URL: http://unisol.com.ua/ index.php (date accessed: 12/05/2014). (Rus.)

11. RockWool: non-combustible insulation. [Electronic resource]. - Access URL: http://www. rockwool.ua/ (date accessed: 12/05/2014). (Rus.)

12. Celotex [Electronic resource]. - Access URL: http://www.celotex.co.uk/products/fr5000 (date accessed: 12/05/2014). (Rus.)

13. Dmytro Zhukov - "Belarusian passive house: To Be, Or Not To Be ...» [Text] // Architecture and building №1 (219) 2011. (Rus.)

14. The first example of a passive house in Belarus [Electronic resource]. - Access URL: http://realt.by/news/article/10548/ (date accessed: 12/05/2014). (Rus.)

15. Energy-efficient building in Goris has opened its doors to 20 families [Electronic resource]. 
- Access URL: http://am.beeca.net/poslednienovosti/250 (date accessed: 05/12/2014). (Rus.)

16. Energy-efficient home. History and development prospects. [Electronic resource]. Access URL: http://www.ecology.md/section. php? section $=$ ecoset\&id $=4928 \# . \mathrm{U} 2 \mathrm{jKyoF} \_\mathrm{vSn}$ (date accessed: 12/05/2014). (Rus.)

17. Green Lighthouse - building sets a new trend in eco architecture. [Electronic resource]. - Access URL: http://www.lightonline.ru/svet/ Architecture/Green_LightHouse.html (date accessed: 12/05/2014). (Rus.)

18. Energy-efficient house: [Electronic resource]. - Access URL: http://www.geaudit.ru/ stati/energoeffektivniy-dom (date accessed: 05/ 12/2014). (Rus.)

19. Energy-efficient house in permafrost conditions has become a reality in Yakutia: [Electronic resource]. - Access URL:http://energodoma.ru/ novosti/novosti/932-energoeffektivnyj-dom-vusloviyakh-vechnoj-merzloty-stal-realnostyu-vyakutii (date accessed: 12/05/2014). (Rus.)

20. The first energy-efficient house opened in Altai Krai. [Electronic resource]. - Access URL: http://www.nanonewsnet.ru/blog/nikst/pervyienergoeffektivnyi-dom-otkryt-v-altaiskom-krae (date accessed: 05/12/2014). (Rus.)

21. The site of the Institute of Thermophysics. S.S. Kutateladze / Ecodom. [Electronic resource]. Access URL: http://www.itp.nsc.ru/ecodom/ (date accessed: 05/12/2014). (Rus.)

22. V.S. Chuntonov. Experience in design of eco house and ecovillage [Text] / V.S. Chuntonov // Scientific and Practical Conference "Energy and resource efficiency of low-rise residential buildings," Institute of Thermophysics. S.S. Kutateladze, Novosibirsk, March 19-20. - 2013. P. 23 - 31. (Rus.)

Получено 19.08.2014

Received 19.08.2014 